\title{
Glucose uptake via GLUT1 maintains T cell survival during proliferative stress
}

\author{
Andrew N Macintvre ${ }^{1 *}$, Valerie A Gerriets ${ }^{1}$, E Dale Able $^{2}$, Jeffery C Rathmell ${ }^{1}$ \\ From Metabolism, diet and disease \\ Washington, DC, USA. 29-31 May 2012
}

\begin{abstract}
Background
Lymphocyte survival is regulated via the balance between pro- and anti-apoptotic BH3 family proteins. In vitro this balance is highly dependent on glucose availability. In vivo, T-lymphocytes develop in the thymus and then exit to the periphery, where they continually migrate until they encounter cells presenting viral/bacterial antigens. This encounter activates the $\mathrm{T}$ cell and induces both proliferation and differentiation into functionally mature $\mathrm{T}$ cell subsets. The role of glucose metabolism in regulating cell survival during each of these stages of the $\mathrm{T}$ cell life cycle is still unclear; however, we have recently demonstrated that different $\mathrm{T}$ cell functional subsets demonstrate distinct metabolic profiles. In vivo manipulation of $\mathrm{T}$ cell glucose metabolism may therefore represent a novel strategy to manipulate immune responses. In order to explore this area we generated mice with a $\mathrm{T}$ cell specific deletion of GLUT1, a major glucose transporter in T cells.
\end{abstract}

\section{Materials and methods}

Mice containing loxP flanked Slc2a1 (encoding GLUT1) [1] were crossed with mice expressing Cre under a T cell specific Lck promoter. Mice with tandem myc tags knocked into an exofacial loop of GLUT1 were generated in-house. Biochemical, metabolic profiling and in vivo proliferation assays were performed as described [2].

\section{Results}

GLUT1 expression was assayed during T cell development, $\mathrm{T}$ cell activation and in mature $\mathrm{T}$ cells. Expression of GLUT1 was limited to lymphocytes undergoing rapid proliferation, with only developing and activated $\mathrm{T}$ cells exhibiting surface expression of GLUT1. Across the

\footnotetext{
${ }^{1}$ Department of Pharmacology and Cancer Biology, Department of Immunology and Sarah W. Stedman Center for Nutrition and Metabolism, Duke University Medical Center, Durham, NC 27710, USA Full list of author information is available at the end of the article
}

mature $\mathrm{T}$ cell subsets, immunosuppressive regulatory $\mathrm{T}$ cells (Treg) demonstrated far lower GLUT1 expression in comparison to pro-inflammatory effector T cells (Teff). These differences correlated with differing rates of glucose consumption. Deletion of GLUT1 from developing T cells using a $L c k C r e S l c 2 a 1^{f l / f l}$ mouse model caused a severe reduction in the number of $\mathrm{T}$ cells in both the thymus and periphery. One exception to this was the Treg cells, the relative proportion of which increased. Naïve T cells lacking GLUT1 were viable, however when induced to proliferate either in vitro or in vivo they were unable to correctly upregulate their glucose metabolism, resulting in a misbalance of $\mathrm{BH} 3$ family proteins and induction of cell death.

\section{Conclusions}

Tight regulation of the glucose transporter GLUT1 is required for normal $\mathrm{T}$ cell development and activation. GLUT1 mediated glucose transport is required to drive $\mathrm{T}$ cell proliferation and to maintain cell survival. One exception to this is the Tregs, which are far less dependent on GLUT1 for survival. Manipulating GLUT1 mediated glucose metabolism may therefore represent a novel therapeutic strategy to skew $\mathrm{T}$ cell responses in vivo.

\footnotetext{
Author details

'Department of Pharmacology and Cancer Biology, Department of Immunology and Sarah W. Stedman Center for Nutrition and Metabolism, Duke University Medical Center, Durham, NC 27710, USA. Division of Endocrinology, Metabolism and Diabetes and Program in Molecular Medicine, University of Utah School of Medicine, Salt Lake City, UT84132, USA.

Published: 1 June 2012

\section{References}

1. Young CD, Lewis AS, Rudolph MC, Ruehle MD, Jackman MR, Yun UJ, Ilkun O, Pereira R, Abel ED, Anderson SM: Modulation of glucose transporter 1 (GLUT1) expression levels alters mouse mammary tumor cell growth in vitro and in vivo. PLoS One 2011, 6:e23205.
} 
2. Coloff JL, Macintyre AN, Nichols AG, Liu T, Gallo CA, Plas DR, Rathmell JC: Akt-dependent glucose metabolism promotes $\mathrm{Mcl}-1$ synthesis to maintain cell survival and resistance to Bcl-2 inhibition. Cancer Res 2011, 71:5204-5213.

doi:10.1186/1753-6561-6-S3-P33

Cite this article as: Macintvre et al:: Glucose uptake via GLUT1 maintains T cell survival during proliferative stress. BMC Proceedings 2012 6(Suppl 3):P33.

Submit your next manuscript to BioMed Central and take full advantage of:

- Convenient online submission

- Thorough peer review

- No space constraints or color figure charges

- Immediate publication on acceptance

- Inclusion in PubMed, CAS, Scopus and Google Scholar

- Research which is freely available for redistribution

Submit your manuscript at www.biomedcentral.com/submit 